\title{
Local, global and regional shocks indices in emerging exchange rate markets ${ }^{\text {is }}$
}

\author{
F. Pinar Erdem ${ }^{\text {a }}$, Utku Bora Geyikci ${ }^{\text {a,b, * }}$ \\ ${ }^{a}$ Central Bank of the Republic of Turkey, Istiklal Cad. No:10, 06100, Ulus, Ankara, Turkey \\ b Bilkent University, 06800, Bilkent, Ankara, Turkey
}

\section{A R T I C L E I N F O}

\section{JEL classification:}

G10

G15

F31

\section{Keywords:}

Forward unbiasedness hypothesis

Exchange rates

Emerging market economies

\begin{abstract}
A B S T R A C T
Impact of exchange rate shocks on emerging market economies have been studied extensively; however, what is the origin of those shocks remains unanswered in the literature. The main aim of this paper is to fill this gap. We identify local, regional and global shocks in exchange rate markets for 19 major EMEs on a daily basis by using forward rate unbiasedness hypothesis. We find an asymmetry on the effects of both local and global shocks and also show that depreciating effects of both local and global shocks dominate the appreciating effects for almost all countries sampled. Moreover, we find that the external vulnerability indicators and financial development indicators are the main sources of the level of shocks.
\end{abstract}

\section{Introduction}

Emerging Market Economies (EMEs) have become more connected to the global financial system since the early 1990s. As Aizenman \& Pinto (2011) noted, the period of growing external financial integration coincided with economic and financial crises in these economies, such as Mexican crises in 1986 and 1994, Turkish crises in 1994 and 2001, the East Asian Crisis in 1997 and the Russian crisis in 1998. Increasing financial integration and the experiences of EMEs have led to the emergence of a whole new literature exploring the factors that affect EMEs' financial markets.

Earlier studies focused on identifying shocks with macroeconomic consequences and mainly aimed to see whether external or domestic factors drive the movements in the economies. Calvo et al. (1993), Fernandez-Arias and Montiel (1996), Kim (2001), Lane (2003), Maćkowiak (2007), and Izquierdo, Romero and Talvi (2008), Forbes and Warnock (2012), Burger et al. (2015), Byrne and Fiess (2016), suggested that not only the domestic factors, but also the global factors determine the fluctuations in capital flows and in business cycles. On the other hand, Chuhan et al. (1998), Taylor and Sarno (1997), Brana and Lahet (2010), Cerutti et al. (2019) argued that local factors have as much importance as the global ones. Fratzscher (2012) suggested that pull factors are the main determinant of capital flows to EMEs whereas push factors take stage in case of crisis. Koepke (2019), on the other hand, claimed that push factors are more important for portfolio debt and equity flows, but their importance lessen in banking flows.

Dailami et al. (2008) and Kennedy and Palerm (2014) focused on the emerging bond markets and aimed to determine whether global or local factors are more effective in emerging market bond spreads. Dailami et al. (2008) emphasized that global factors, mainly the US interest rates, significantly affected the EME bond spreads depending on countries' debt levels. Kennedy and Palerm (2014) reported

the views expressed in the article are those of the authors and do not necessarily reflect those of the Central Bank of the Republic of Turkey nor of its members. This paper is a part of Utku Bora Geyikçi's Ph.D. study in the Faculty of Business Administration in I.D. Bilkent University.

* Corresponding author. Central Bank of the Republic of Turkey, Istiklal Cad. No:10, 06100, Ulus, Ankara, Turkey.

E-mail addresses: pinar.erdem@tcmb.gov.tr (F.P. Erdem), utku.geyikci@tcmb.gov.tr, bora.geyikci@bilkent.edu.tr (U.B. Geyikci). 
Table 1

Fixed effects estimations for local, global and regional shocks.

\begin{tabular}{|c|c|c|c|c|c|c|}
\hline \multirow{2}{*}{ VARIABLES } & \multirow{2}{*}{$\frac{(1)}{\text { Local }}$} & \multirow{2}{*}{$\frac{(2)}{\text { Local }}$} & \multirow{2}{*}{$\frac{(3)}{\text { Global }}$} & \multirow{2}{*}{$\frac{(4)}{\text { Global }}$} & \multirow{2}{*}{$\frac{(5)}{\text { Regional }}$} & \multirow{2}{*}{$\frac{(6)}{\text { Regional }}$} \\
\hline & & & & & & \\
\hline Inflation & -0.0005 & -0.0004 & -0.0002 & -0.0002 & -0.0001 & -0.0001 \\
\hline$\Delta$ External Debt/GDP & $0.0012^{* * *}$ & & -0.0002 & & 0.0002 & \\
\hline$\Delta$ Public Debt/GDP & 0.0022 & & 0.0005 & & -0.0000 & \\
\hline Foreign Holdings Share & $-0.1755^{*}$ & $-0.2032^{*}$ & $-0.1684 * * *$ & $-0.1632^{* * *}$ & -0.0224 & -0.0254 \\
\hline Market Capitalization & $-0.0003^{* *}$ & $-0.0005^{* * *}$ & $-0.0003^{* * *}$ & $-0.0004 * * *$ & $-0.0001^{*}$ & $-0.0001^{*}$ \\
\hline Import Cover Ratio & & $-0.0010^{* * *}$ & & $-0.0007 * * *$ & & -0.0002 \\
\hline Gov.Budget Balance & & $-0.0001^{* *}$ & & -0.0001 & & -0.0001 \\
\hline Observations & 507 & 492 & 507 & 492 & 507 & 492 \\
\hline R-squared & 0.204 & 0.177 & 0.291 & 0.308 & 0.026 & 0.032 \\
\hline Number of Counties & 15 & 15 & 15 & 15 & 15 & 15 \\
\hline
\end{tabular}

Robust standard errors in brackets.

$* * * \mathrm{p}<0.01, * * \mathrm{p}<0.05, * \mathrm{p}<0.1$.

Note: Peru, Korea, Czechia and Colombia are not included in the estimations due to limited data.

Table 2

Estimation results for GMM.

\begin{tabular}{|c|c|c|c|c|c|c|}
\hline \multirow{2}{*}{ VARIABLES } & \multirow{2}{*}{$\frac{(1)}{\text { Local }}$} & \multirow{2}{*}{$\frac{(2)}{\text { Local }}$} & \multirow{2}{*}{$\frac{(3)}{\text { Global }}$} & \multirow{2}{*}{$\frac{(4)}{\text { Global }}$} & \multirow{2}{*}{$\frac{(5)}{\text { Regional }}$} & \multirow{2}{*}{$\frac{(6)}{\text { Regional }}$} \\
\hline & & & & & & \\
\hline$\Delta$ Local & -0.0862 & 0.0099 & & & & \\
\hline Inflation & 0.0001 & -0.0002 & -0.0001 & -0.0001 & 0.0002 & 0.0001 \\
\hline$\Delta$ External Debt/GDP & $0.0007^{* * *}$ & & 0.0001 & & $0.0003^{* * *}$ & \\
\hline$\Delta$ Public Debt/GDP & $0.0017^{*}$ & & $0.0021 * *$ & & -0.0002 & \\
\hline Foreign Holdings Share & $-0.1801 * * *$ & $-0.1953^{* * *}$ & $-0.3849 * * *$ & $-0.4127 * * *$ & $-0.0450 * * *$ & $-0.0603^{* * *}$ \\
\hline Market Capitalization & $-0.0002^{* * *}$ & $-0.0003^{* * *}$ & $-0.0003^{* * *}$ & $-0.0002^{* * *}$ & $0.0001 * * *$ & $0.0001 * *$ \\
\hline Import Cover Ratio & & $-0.0006^{* * *}$ & & $-0.0017 * * *$ & & -0.0005 \\
\hline Government Budget Balance & & $-0.0002^{* * *}$ & & -0.0002 & & -0.0000 \\
\hline$\Delta$ Global & & & -0.0630 & -0.0362 & & \\
\hline$\Delta$ Regional & & & & & -0.0146 & -0.0388 \\
\hline Observations & 507 & 492 & 507 & 492 & 507 & 492 \\
\hline Number of Countries & 15 & 15 & 15 & 15 & 15 & 15 \\
\hline $\operatorname{AR}(1)$ & -1.805 & -2.677 & -2.922 & -3.056 & -2.728 & -2.482 \\
\hline $\operatorname{AR}(2)$ & -1.344 & -1.349 & 1.538 & 1.542 & 0.028 & -0.212 \\
\hline Sargan Test & 10.529 & 8.116 & 11.749 & 11.929 & 11.319 & 11.445 \\
\hline
\end{tabular}

Standard errors in brackets.

$* * * \mathrm{p}<0.01, * * \mathrm{p}<0.05, * \mathrm{p}<0.1$.

Note: Test statistics are given for AR(1), AR(2) and Sargan tests. Findings indicate that there is first order autocorrelation in errors and no higher order autocorrelation for error terms. In addition according to Sargan test instruments choosen are valid.

that, before the global financial crisis (GFC), local factors dominated global ones whereas the increase in spreads during the GFC was caused by mainly global factors. Another group of studies investigated the effects of global and local factors on the CDS spreads of the EMEs. Hibbert and Pavlova (2017), for example, presented that CDS spreads have high communalities. They claimed that global factors mostly affect Latin America spreads whereas local factors are more important for European spreads.

Shocks to exchange rates have drawn special attention in the EMEs as this is the "most important indicator of vulnerability in EMEs" (Siklos, 2018, p. 174) while such movements also have serious effects on the real economy (Forbes et al., 2018). Similarly, Ghosh et al. (2016) presented that exchange rates play a more central role in EMEs than in advanced economies. Moreover, exchange rates can be considered as the first line of defence for EMEs against any type of shocks, in particular, across countries with floating exchange rate regimes. It is discussed widely in the literature that flexible exchange rates have acted as shock absorbers and helped countries to accommodate shocks. ${ }^{1}$ However, Forbes et al. (2018) noted that studies on exchange rates have mostly focused on the impact of exchange rate shocks on the macroeconomic outlook of the countries, while the question of what causes those shocks remains unanswered. Although many studies aimed to identify determinants of capital flows, bond markets and CDS spreads in EMEs, to the best of our knowledge, no study has aimed to decompose shocks in foreign exchange markets. The main motivation in this study is to decompose the shocks in the foreign exchange markets in daily frequency Furthermore, in the next step it is aimed to examine how the level of these shocks alter by a country's macro-finance outlook.

In order to identify shocks in foreign exchange markets, forward rate unbiasedness hypothesis (UBH) is used in this study. UBH has been one of the most frequently studied and controversial topic in the area of international finance. The uncovered interest rate parity

${ }^{1}$ See Edwards and Yeyati (2005). 
(UIP) theory suggests that the expected exchange rate change should equal to the forward premium (the difference between the forward and spot rates) under no arbitrage condition. Thus, under UIP with no arbitrage condition, it is highlighted that the forward exchange rate may be an unbiased forecast of the future spot exchange rate which is suggested by the UBH. ${ }^{2}$ On the other hand, the unbiasedness of forward exchange rates has been overwhelmingly rejected in numerous studies. And, the failure of UBH is considered as the failure of efficient market conditions. Failure of UBH indicates a deterioration in markets associated with failure of rational expectations and risk neutrality assumptions in the markets. On the other hand, Ismailov and Rossi (2018) suggest that the UBH fails due to the presence of a risk-premium on the exchange rates stemming from the risk averse characteristics of the investors. Fama (1984), in his preliminary study, concluded that the expected change in the exchange rate is inversely related to the forward premium. Similarly, Kumar and Trück (2014) used futures rates to test the unbiasedness hypothesis and they concluded that the futures premium cannot be considered as an unbiased predictor of changes in the spot rate for Indian exchange rate market. For the rational expectations assumption, according to Froot and Thaler (1990), bias is related with the expectational errors of the investors. Similarly, Lewis (1995) also argued the important component in forward bias is the forecast error, not the risk premium. There are also studies that presented explanation for solving the bias. Flood and Rose (1995) claimed that the UIP works better under fixed exchange rate regimes while Chinn and Meredith (2004) provided evidence to support that the UIP holds for longer time horizon. Nikolaou and Sarno (2006) studied the options market to predict future exchange rates and their findings suggested the existence of an "options bias" similar to the "forward bias". However, when they controlled for endogeneity to cover the unobserved risk premium, they concluded forward rates are unbiased predictors of the future spot rates.

In this study, rather than focusing on the validity of assumptions of the UBH, we followed the asset pricing approach developed by Levich (1983), who maintained that exchange volatility is affected by the expectations. As Dos Santos et al. (2016) stated, under no arbitrage condition, forward exchange rates should reflect all the available information. Therefore, only the unanticipated events have an effect on the exchange rates, which imply that the difference between the forward rates and the concurrent spot rates (forward bias) are the unanticipated news/shocks. This paper aims to construct an exchange rate shock indices for EMEs based on this bias.

This paper revisits the UBH and based on the bias, local, regional and global factor indices for exchange rate markets in EMEs are developed. As the first step, the UBH is tested and the findings provide evidence for the rejection of the UBH for all of the countries, which enables us to use the spread between forward exchange rates and concurrent spot exchange rates as shocks. And by statistical framework, total shocks are decomposed into global, regional and local shock components. In the second part of the study, which characteristics of a country amplify/mitigate the shocks is discussed.

This study contributes to the literature in two-ways. Firstly, we decompose local, regional and global shock indices for EMEs on a daily-basis. Daily-basis indices enable policy makers to monitor risks in exchange rate markets and may provide insight into the origin and the size of the shocks in order to develop efficient policy responses in a timely manner. Findings indicate that the computed indices are strongly in line with both local and global developments. In addition, descriptive statistics of indices show that the depreciating effects of both local and global shocks dominate the appreciating effects for almost all countries in the sample. Statistics support the view that EMEs are more sensitive to negative shocks. Secondly, how a country's macro-finance stance affects the level of shocks is examined in order to understand why some countries experience sharper or smoother shocks in their financial markets. Empirical findings indicate that external vulnerability indicators and financial development indicators are the main sources of the level of shocks.

The remainder of the article is organized as follows: the second section presents the data and methodology; the third section reports the results; in the fourth section the linkage between macro-financial and local, regional and global shock indices are examined, and the last section concludes.

\section{Data and methodology}

Our sample includes daily forward and spot exchange rates for 19 major EMEs over the period January 2nd, 2010 to March 9th,2019. ${ }^{3}$ Early studies used the base level model given in equation (1) to test UBH. ${ }^{4}$

$$
\mathrm{s}_{\mathrm{t}+30}^{\mathrm{i}}=\alpha^{\mathrm{i}}+\beta_{1}^{\mathrm{i}} \mathrm{f}_{\mathrm{t}}^{\mathrm{i}}+\varepsilon_{\mathrm{t}+30}^{\mathrm{i}}
$$

where $s_{t+30}^{i}$ is the spot exchange rate of country $i$ at time $t+30$ and $f_{t}^{i}$ is the one-month forward exchange rate $e^{5}$ of country $i$ at time $t$, both in logarithmic form, while $\varepsilon$ is the white-noise error term. Under the forward unbiasedness hypothesis, $\alpha^{\mathrm{i}}$ is allowed to equal some constant whereas $\beta_{1}$ is expected to be equal to 1 . $^{6}$

However, spot and forward exchange rates are non-stationary in some countries, ${ }^{7}$ so, using equation (1) would give misleading results. Thus, in this study, the recent approach, the so-called difference equation, is taken into account in order to avoid overestimation of the relationship among non-stationary series and to produce reliable and interpretable results. The difference equation given in (2),

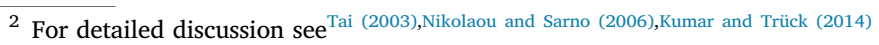

3 Countries: Brazil, Bulgaria, Chile, Colombia, Czech Republic, Hungary, India, Indonesia, Korea, Malaysia, Mexico, Peru, Philiğğines, Poland, Romania, Russia, South Africa, Thailand and Turkey.. The data source is Bloomberg.

4 See Frankel (1979), Maynard (2003), Chinn (2007), Frankel and Poonawala (2010).

5 Forward exchange rates are computed as $F_{t}^{i}=S_{t-30}^{i}+F P_{t-30}^{i}$, where FP is the forward premium.

6 See Chinn (2007).

7 Reported in Table A2.
} 
which is widely used in the literature, is estimated by using Generalized Autoregressive Conditional Heteroscedasticity (GARCH) for each country in the sample.

$$
s_{t+30}^{i}-s_{t}^{i}=\delta^{i}+\beta_{2}^{i}\left(f_{t}^{i}-s_{t}^{i}\right)+\mu_{t+30}^{i}
$$

where $\left(s_{t+30}^{i}-s_{t}^{i}\right)$ is the ex-post future percentage depreciation/appreciation; $\left(f_{t}^{i}-s_{t}^{i}\right)$ is the forward discount (or inverse of the forward premium) at time $t$; and $\mu$ is the white-noise error term. Under the forward unbiasedness hypothesis, $\delta^{i}$ is allowed to equal some constant whereas $\beta_{2}$ is expected to be equal to 1 .

The first step in decomposing local, regional and global shocks in the foreign exchange markets is obtaining residual terms $\left(\mu_{t+30}^{i}\right)$ for each country from equation (2). Residual terms $\left(\mu_{t+30}^{i}\right)$ are assumed to capture unexpected local, regional and global shocks to a country's foreign exchange market. In the second step, principal component analysis is applied to $\mu_{t+30}^{i}$ for each country to identify the common external shock - the so-called common global factor (CGF). The CGF is the first principal component of the residual terms of countries other than country i. In the next step, the following equation (3) is estimated by GARCH to identify the local and regional shocks and measure the global shock to each country's foreign exchange market. Equation (3) uses the residuals from equation (2).

$$
\mu_{t}^{i}=\gamma^{i}+\theta_{1}^{i} C G F_{t}^{i}+\vartheta_{t}^{i}
$$

where $C G F_{t}^{i}$ are common global factors obtained by applying principal components analyses to the residual terms of equation (2) for country $\mathrm{i} ; \gamma$ is the constant term; $\vartheta_{t}^{i}$ are residual terms that involve both regional and local shocks. Estimated $\widehat{\mu_{t}^{i}}$ stand for global shocks reflected in country i's foreign exchange market at time t which could be considered as the country's financial market sensitivity to global shocks. To put it another way, estimated $\widehat{\mu_{t}^{i}}$ provides information on how the global shocks are felt in the financial markets of the specific county.

Sample of countries are grouped in three as: (i) Latin American, (ii) Asian and (iii) Central and Eastern European countries. ${ }^{8}$ Based on the group of countries, principal components of $\vartheta_{t}^{i}$ are obtained separately and accepted as regional factors: Asian Factor (AF), Latin American Factor (LAF) and CEE Factor (CEEF).

$$
\vartheta_{t}^{i}=\partial^{i}+\rho_{1}^{i} \text { Regional }_{t}^{i}+\omega_{t}^{i}
$$

Regional factor stands for the regional common element for each country based on the country groups. Estimated $\widehat{\vartheta_{t}^{i}}$ stands for regional shocks reflected in country i's foreign exchange market at time $t$ which could be considered as the country's financial market sensitivity to regional shocks. Residual terms $\omega_{t}^{i}$ are accpeted as local shock indices which is the final residual after global and regional shocks are eliminated from the estimated total shock by equation (2).

\section{Identifying local, regional and global shocks in emerging market economies}

Table A1 presents the unit root test results for both spot and forward exchange rates. ${ }^{9}$ These indicate that spot and forward exchange rates of Bulgaria, Colombia, Czechia, Hungary, South Korea, Malaysia, Peru, Philippines, Romania and Thailand were stationary whereas other currencies were stationary at first differences at $5 \%$ significance level.

Based on the estimation of equation (2) for each country, the unbiasedness hypothesis is tested, as reported in Appendix A2. The hypothesis is rejected for all currencies, which is consistent with the literature. The results indicate that forward exchange rates in EMEs are biased estimators of future spot exchange rates, so, the residuals between spot and forward rates can be taken as proxies of unexpected events. Decomposing these residuals could show if the unexpected events, both positive and negative, originated mainly from domestic, regional or external factors. Appendix A3 presents the identified shocks for each country based on equation (2) ${ }^{10}$.

An increase in the indices indicates rising negative risks; in other words, there are exchange rate depreciating shocks while a decrease in the indices shows falling negative risks or favourable developments in the FX markets. The identified factors are in line with local and global developments in each county. The sharp rises identified in local factors in Brazil, Mexico, Russia, Turkey and South Africa are consistent with local events that led to high volatility in these financial markets. More specifically, local factor indices in Brazil and South Africa have fluctuated due to political uncertainty since 2015. The depreciation of the Brazilian real during spring 2018, due to domestic political tensions, the depreciating effects of the USA elections in November 2016 and political tensions with the USA in the summer of 2018 on Mexican peso are observed to be remarkable in the graphs. Furthermore, the impacts of sharp decrease in oil prices and sanctions imposed by the US and the EU in the second half of 2014 in Russian FX markets could also be observed clearly.

In order to demonstrate the global, regional and local shocks more clearly, the important shocks on Turkey's graph are presented in Appendix A4. As seen in the graph, there is no significant regional shock to Turkey. However, until the beginning of 2015, Turkey had been more exposed to global shocks. European debt crisis in May 2010, October 2011, and the tapering talk in May 2013 increased the

\footnotetext{
${ }^{8}$ Latin America Countries: Brazil, Chile, Colombia, Mexico and Peru; Asian Countries: India, Indonesia, Malaysia, Philippines South Korea and Thailand; Central and Eastern Europe: Bulgaria, Czechia, Hungary, Poland, Russia, Romania, Turkey, South Africa.

${ }^{9}$ Augmented Dickey Fuller test with intercept is conducted for each country.

${ }^{10}$ Based on equation (1) similar results are obtained but not reported due to space constraints. Upon request findings could be provided.
} 
risks in Turkey. Until then local shocks had been the main source of volatility. Particularly, political events such as the 17-25 December operations in 2013, June elections in 2015, coup attempt in July 2016, Fitch downgrade in January 2017 and the US visa crisis in October 2017 increased the volatility in Turkey. The sharp and rapid depreciation of Turkish lira in August 2018 could also be observed. In addition, movements in local factor indices coincide with the movements in global financial markets since the November 2016 US elections are thought to have increased global risks.

Common global shocks such as the European debt crisis in 2011, tapering talk in May 2013 and the US Elections in November 2016 can be observed to have resulted in an increase in global factor indices for almost all EMEs. Global factors, however, have made only a limited contribution to the divergence between forward and future spot rates in Chile, India, Indonesia, Malaysia, Peru, Philippines and Thailand which have lowest average positive and negative global shocks level given in Table A8. The underlying factors of this outcome could be: (i) local factors dominate exchange rate markets; (ii) in countries with managed regimes, global factors can be expected to have less impact on foreign exchange markets; (iii) the prediction capability of forward rates is higher in more robust financial markets; and (iv) these countries have stronger macro-finance indicators such as sustainable level of external debt or stronger financial development which is discussed in the next section. Both local, regional and global factors moved in a narrow band in Korea, Malaysia, Peru, Philippines and Thailand, which implies that these foreign exchange markets experienced fewer shocks and had a more stable pattern. This observation could also be related with these countries' external debt levels which are helpful to smooth the impact of shocks. For instance, the average external debt to GDP for the whole sample is around 47\% while Korea and Philippines' gross external debts to GDP ratio are around $30 \%$. In addition, financial development indicators of Korea, Malaysia and Thailand are stronger compare to other countries which could mitigate the impacts of negative shocks.

On the other hand, regional factors are strong mainly in Bulgaria, Czechia, Hungary, Poland and Romania which are members of the EU. Therefore, a close connection of these countries with other EU countries could possibly make them very sensitive to the developments in euro zone. Other countries in our sample, namely the Eastern Europe (Russia, Turkey and South Africa) presented nearly no regional effects, which also validates the significance of the EU for member countries. In Latin America, it is also observed that regional effects in Brazil, Chile, Colombia and Peru are quite high whereas Mexico exhibits nearly no regional effects.

Appendix A5 presents the descriptive statistics for the local shocks in each country. On average, the Turkish lira has undergone the highest depreciation effect caused by the local shocks followed by the Russian ruble and Colombian peso whereas Korean won, Brazilian real and Chilean peso has the highest appreciating effects resulted from the local shocks. Indeed, rather than Brazilian real, Korean won, Chilean peso and Philippines peso, on average, all currencies have dominated by depreciating local shocks. In order to understand the asymmetric impacts of local shocks, the shocks are divided into two categories; positive shocks and negative shocks. Appendix A6 demonstrates that negative events happen more often than the positive ones and the magnitude of negative shocks are higher than that of the positive shocks. This shows not only the dominance of negative unexpected events in the emerging markets but also the asymmetry in the reaction to the shocks. Moreover, volatility of the local shocks varies significantly across currencies. Overall, the Russian ruble and the Turkish lira have the highest volatility over the local shocks whereas the Bulgarian lev and the Peruvian sol have the lowest volatility which implies that these currencies have higher predictability or have experienced less unanticipated shocks.

Appendix 7 shows the descriptive statistics for the global shocks. On average, the Brazilian real, the Korean won and the South African rand have shown the highest depreciation effect caused by global shocks whereas the Colombian peso, the Indian rupee and the Philippines peso demonstrate the highest appreciation effect due to the global shocks. Similar to local shocks, depreciating effects of the global shocks have higher magnitude and frequency than the appreciating effect of the shocks (Appendix A8). Although the Polish zloty seems to be affected less than the average by global shocks, it has the highest volatility. When we divide our sample into two; positive shocks and negative shocks, we observe that the Polish zloty is the currency that is affected the most from the positive shocks and the second most from the negative shocks which, in turn, increases volatility. Although all currencies give asymmetric reactions to the global shocks, the Brazilian real and the Colombian peso have shown the most asymmetric reactions to the global shocks. On the one hand, the impact of the negative news largely outscores the impact of the positive news in the case with the Brazilian real, which makes real the most negatively affected currency in our sample. On the other hand, the Colombian peso responds more effectively to the positive news, which leads the currency to becoming the most appreciated compared to other currencies.

Appendix 9 has the descriptive statistics for the regional shocks. Positive and negative shocks appear to have equal dominance in regional shocks; half of the currencies are affected more from the positive shocks; other half are affected more from the negative shocks. When we look at the effects of positive and negative shocks separately, it is seen that the effect effects of regional shocks are much less than those of both global and local shocks (Appendix 10). The most affected currencies from the regional shocks are the Czech koruna, the Hungarian forint, the Romanian leu, the Colombian peso, the Bulgarian lev and the Polish zloty.

Appendix 11 reports the descriptive statistics of the total shocks. T-statistics of the mean of the currencies is found to be significant at the 5 percent level, except from the Hungarian forint, the Polish zloty, the Bulgarian lev, the Czech koruna, the Philippines peso, the Romanian leu and the Colombian peso, which has an implication for the carry trade returns. Since most of the carry trade is unhedged, investors take the exchange rate risk to gain the interest rate and, when the exchange rate depreciates more than expected, gains from carry trade decreases. Therefore, particularly, investors who invest in Turkish lira, Russian ruble and Brazilian real, on average, realize a decline in their carry returns due to the unexpected events. Therefore, investors may demand higher risk premium for those currencies. When we order the currencies according to their average of carry returns ${ }^{11}$ (Appendix 12), it is seen that the highest carry return

$\overline{11}$ Carry return is calculated as the 1-month FX swap rate minus 1-month US Libor rate. 
currencies are the Turkish lira, the Brazilian real and the Russian ruble, which supports our analysis. It should also be noted that these currencies have undergone the highest depreciating effect during local shocks.

\section{Regression analysis}

In the previous section, local, regional and global indices for each country are extracted and analysed. Estimated global, regional and local shock indices stand for the countries' sensitivities to a particular shock. In this section, the aim is to examine how country-specific characteristics and indices are associated and to understand if countries' fundamental macroeconomic indicators have a significant impact on the level of the shocks. In other words, an answer for the question of how macroeconomic indicators affect the degree of the shocks is sought by using panel data estimations. The answer of this question is important for policy makers that it provides information on which macroeconomic indicator improvement (deterioration) could mitigate (increase) the impact of a negative (positive) shock significantly.

Macro-financial indicators of a country that are proxies for both domestic and external vulnerabilities as well as financial depth indicators are taken into account in order to analyse how the magnitude of these shocks differs with country specific characteristics. ${ }^{12}$ The link between shocks and country specific characteristics are analysed by employing fixed effects panel estimations based on equations (6)-(8).

$$
\begin{aligned}
& \text { Global }_{i t}=\alpha+\gamma Z_{i t}+\epsilon_{i t} \\
& \text { Regional }_{i t}=\alpha++\gamma Z_{i t}+\epsilon_{i t} \\
& \text { Local }_{i t}=\alpha++\gamma Z_{i t}+\epsilon_{i t}
\end{aligned}
$$

$\widehat{\varepsilon_{t}^{i}}$ as global shock index, $\widehat{\tau_{t}^{i}}$ regional shock index and $\phi_{t}^{i}$ as local index are used for Global ${ }_{\text {it }}$, Regional ${ }_{\text {it }}$ and Local ${ }_{\text {it }}$ respectively. $\mathrm{Z}_{\mathrm{it}}$ represents the country specific characteristics. For country specific characteristics inflation outlook, external debt to GDP ratio, public debt to GDP ratio, government budget balance, foreign holding ratio in local bonds market, international reserves to imports ratio and market capitalization to GDP ratio are taken into account. ${ }^{13}$ Foreign holding ratio in local bonds market and market capitalization to GDP ratio are taken into account since they are proxies for financial development. International reserves to imports ratio is an indicator for reserve adequacy. External debt to GDP ratio is important since it indicates how the country's economy depends on external financing. Government debt to GDP ratio and government budget balance have noteworthy impact on country's risk premium. All of the variables could shape the perception of risk for the related country. Since many of the country specific indicators are in quarterly basis; average of the local, regional and global indices are used in the estimations. All of these country specific variables could have been affected by the local, regional and global shocks through lags as it is widely discussed in the literature that the global financial crisis in 2008 implies financial shocks could have significant consequences on macroeconomic fundamentals. ${ }^{14}$ Thus, in order to control for endogeneity problem, average of shock indices are used within a quarter and also robustness of the estimation is tested by conducting Arellano and Bover (1995) dynamic panel data GMM estimators. In this study, we focus on how these country specific factors alter the impact of shocks to understand better why some countries have experienced sharper or smoother shocks in their financial markets.

The effects of the country specific variables are represented on the shocks in Table 1 . The results are generally in line with the expectations. It is seen that the inflation outlook has no significant impact on the level of shocks. Remarkable decline in inflation levels have been observed in many EMEs since the second half of 2000s, after long period of high inflation. Thus, it is expected that the inflation outlook has no more significant role as to amplify or mitigate the impacts of shocks.

External debt level and import cover ratio have significant impact on the level of local shocks. While increase in external debt level amplifies any local originated shock, stronger international reserves could mitigate the impact of adverse local shocks significantly. On the other hand, findings indicate that the external vulnerability indicator has a limited impact on the level of global shocks. While stronger international reserves could also mitigate the impact of adverse global shocks, the external debt level is not a significant determinant of the global shocks. As Bruno and Shin (2015) stated, the total stock of the US dollar-denominated debt of corporates in EMEs surged after the global financial crisis. Foreign currency borrowing helps EMEs to mitigate financial frictions. However, as Bruno and Shin (2015) stressed, increase in foreign currency denominated debt could increase the external vulnerability in an environment of currency depreciation via adverse balance sheet valuation effects on borrowers. Thus, our finding for the impacts of external vulnerability indicators is line with the findings of Bruno and Shin (2015). On the other hand, the public debt level has no significant impact on shocks. However, it is found debt budget balance has a significant impact on local shock such that a surplus government budget balance could be a buffer and mitigate the adverse effects of local shocks.

Financial development indicators, both foreign holdings share in local bond markets and market capitalization ratio, are strongly significant for both local and global shocks. Financial development in EMEs have increased notably in the last two decades. The increase in financial development has two aspects. (i) raising EMEs' exposure to global financial shocks and (ii) increasing their flexibility to

\footnotetext{
12 For the selection of the various explanatory variables see Calvo et al. (1993) and Aizenman and Binici (2016).

${ }^{13}$ Data are obtained from Datastream and Bloomberg.

${ }^{14}$ See Gilchrist et al. (2009) and Jermann and Quadrini (2012).
} 
reach external funding channels and increasing the resilience of these countries. Our findings support the latter one. The higher foreign holdings share in local bond markets and higher market capitalization could reduce the impact of local and global shocks which implies that financial development indicators act as stabilizers. On the linkage between country specific characteristics and regional shocks, market capitalization rate has only significant but limited impact.

In Table 2, dynamic panel data GMM estimation results are presented. GMM results, in order to control for the endogeneity problem, support the findings of fixed effects estimations. While inflation outlook has no significant impact on the level of shocks, financial depth indicators, both foreign holdings share in local bond markets and market capitalization ratio, have strong significant impact on the level of global and local shocks. In line with previous findings, improvement in financial depth indicator mitigate the impact of negative shocks and increase the impact of positive shocks in the financial markets. In addition, external debt level has a significant impact on the level of local shocks and import cover ratio has a significant impact both on the level of local and global shocks. Different from the previous results, it is seen that public debt ratio has a significant impact on the local and global shocks as a result of GMM estimations.

\section{Conclusion}

Researchers have paid increasing attention to identifying shocks to exchange rates, particularly in the EMEs, since exchange rates are shock absorbers that help countries to accommodate shocks. In this framework, this study aimed to identify the local, regional and global factors in exchange rate movements and to develop high frequency local and global factor indices for EMEs.

We introduce daily global, regional and local shock indices that were extracted from the forward and spot exchange rates of 19 major EMEs. The divergence between forward exchange rates and concurrent spot exchange rates was used to decompose local, regional and global shocks because the residuals between spot and forward rates could be taken as proxies of unexpected events. The extracted local, regional and global factor indices match with the local events as well as with global developments. Findings also indicate the presence of asymmetry on the effects of both local and global shocks. Shocks that have depreciating and appreciating effects differ in magnitude across countries. This outcome is in line with the expectations that some currencies are more sensitive to negative news compared to positive ones.

Moreover, the linkage between countries' macro-financial indicators and level of shocks is examined. It is concluded that the external vulnerability indicators and financial development indicators have significant impact on the level of shocks. Countries with higher external indebtedness are more vulnerable to the shocks whereas countries with higher financial development levels have experienced smoother shocks compared to others.

These findings indicate that the global, regional and local shock indices developed from the residuals between forward exchange rates and concurrent spot exchange rates are interpretable and demonstrate how both global and local developments can impact foreign exchange markets in EMEs. Daily-basis indices could contribute to policy developing process in order to respond with efficient tools to adverse shocks as they enable a comparison of shocks with previous periods and among EMEs. Furthermore, according to empirical findings, developing reforms in order to reduce external indebtedness level as well as reforms on financial development help to mitigate both adverse local and global shocks.

\section{APPENDIX}

A1

Unit Root Test for Spot and Forward Exchange Rates

\begin{tabular}{|c|c|c|c|c|}
\hline \multirow[t]{2}{*}{ Country } & \multicolumn{2}{|l|}{ Spot Exchange Rates } & \multicolumn{2}{|c|}{ Forward Exchange Rates } \\
\hline & Level & First Difference & Level & First Difference \\
\hline Bulgaria & $-16.625^{* * *}(0.000)$ & $-45.984 * * *(0.000)$ & $-16.854 * * *(0.000)$ & $-45.984 * * *(0.000)$ \\
\hline Brazil & $-0.774(0.825)$ & $-49.114 * * *(0.000)$ & $-0.847(0.804)$ & $-49.114 * * *(0.000)$ \\
\hline Chile & $-1.064(0.732)$ & $-44.036 * * *(0.000)$ & $-1.111(0.714)$ & $-44.036^{* * *}(0.000)$ \\
\hline Colombia & $-25.702^{* * *}(0.000)$ & $-46.351^{* * *}(0.000)$ & $-25.601 * * *(0.000)$ & $-46.351 * * *(0.000)$ \\
\hline Czechia & $-8.570 * * *(0.000)$ & $-46.754 * * *(0.000)$ & $-8.246 * * *(0.000)$ & $-46.754 * * *(0.000)$ \\
\hline Hungary & $-25.918^{* * *}(0.000)$ & $-46.410^{* * *}(0.000)$ & $-25.426^{* * *}(0.000)$ & $-46.410 * * *(0.000)$ \\
\hline Indonesia & $-0.163(0.941)$ & $-44.033^{* * *}(0.000)$ & $-0.481(0.892)$ & $-44.033^{* * *}(0.000)$ \\
\hline India & $-1.177(0.686)$ & $-47.706^{* * *}(0.000)$ & $-1.238(0.686)$ & $-47.706 * * *(0.000)$ \\
\hline Korea & $-3.139 * * *(0.024)$ & $-47.706 * * *(0.000)$ & $-3.061 * * *(0.029)$ & $-47.706^{* * *}(0.000)$ \\
\hline Mexico & $-0.527(0.883)$ & $-44.992^{* * *}(0.000)$ & -0.497 (0.889) & $-44.992^{* * *}(0.000)$ \\
\hline Malaysia & $-5.428 * * *(0.000)$ & $-45.682^{* * *}(0.000)$ & $-5.741 * * *(0.000)$ & $-45.682 * * *(0.000)$ \\
\hline Peru & $-10.048 * * *(0.000)$ & $-45.869 * * *(0.000)$ & $-10.430 * * *(0.000)$ & $-45.869 * * *(0.000)$ \\
\hline Philippines & $-28.966^{* * *}(0.000)$ & $-46.398^{* * *}(0.000)$ & $-28.912^{* * *}(0.000)$ & $-46.398 * * *(0.000)$ \\
\hline Poland & $-1.943(0.312)$ & $-45.834 * * *(0.000)$ & $-2.024(0.276)$ & $-45.834 * * *(0.000)$ \\
\hline Romania & $-6.664 * * *(0.000)$ & $-45.452^{* * *}(0.000)$ & $-7.008^{* * *}(0.000)$ & $-45.452^{* * *}(0.000)$ \\
\hline Russia & $-0.740(0.835)$ & $-48.140 * * *(0.000)$ & $-0.809(0.816)$ & $-48.140 * * *(0.000)$ \\
\hline Thailand & $-10.047^{* * *}(0.000)$ & $-45.869 * * *(0.000)$ & $-10.870 * * *(0.000)$ & $-45.869 * * *(0.000)$ \\
\hline Turkey & $-0.096(0.965)$ & $-47.184 * * *(0.000)$ & $-0.156(0.969)$ & $-47.184 * * *(0.000)$ \\
\hline South Africa & $-1.186(0.682)$ & $-45.150 * * *(0.000)$ & $-1.073(0.728)$ & $-45.150 * * *(0.000)$ \\
\hline
\end{tabular}

* reject unit root at $1 \%$ significance level.

Note: The permitted intercept and lag length were selected by SIC. 
A2

Testing for Forward Rates Unbiasedness Hypothesis

\begin{tabular}{lll}
\hline Currency & Coefficient $(\beta)$ & Wald Test $P$-values $(\beta=1)$ \\
\hline BRL & 0.526 & $0.000^{* * *}$ \\
CLP & 0.576 & $0.000^{* * *}$ \\
IDR & 0.389 & $0.000^{* * *}$ \\
INR & 0.463 & $0.000^{* * *}$ \\
KRW & 0.494 & $0.000^{* * *}$ \\
MXN & 0.529 & $0.000^{* * *}$ \\
PLN & 0.479 & $0.000^{* * *}$ \\
RUB & 0.390 & $0.000^{* * *}$ \\
ZAR & 0.529 & $0.000^{* * *}$ \\
TRY & 0.485 & $0.000^{* * *}$ \\
CZK & 0.594 & $0.000^{* * *}$ \\
HUF & 0.585 & $0.000^{* * *}$ \\
COP & 0.386 & $0.000^{* * *}$ \\
PEN & 0.479 & $0.000^{* * *}$ \\
THB & 0.043 & $0.000^{* * *}$ \\
MYR & 0.515 & $0.000^{* * *}$ \\
PHP & 0.491 & $0.000^{* * *}$ \\
RON & 0.566 & $0.000^{* * *}$ \\
BGN & 0.516 & $0.000^{* * *}$ \\
\hline
\end{tabular}

*significant at $1 \%$ level. 


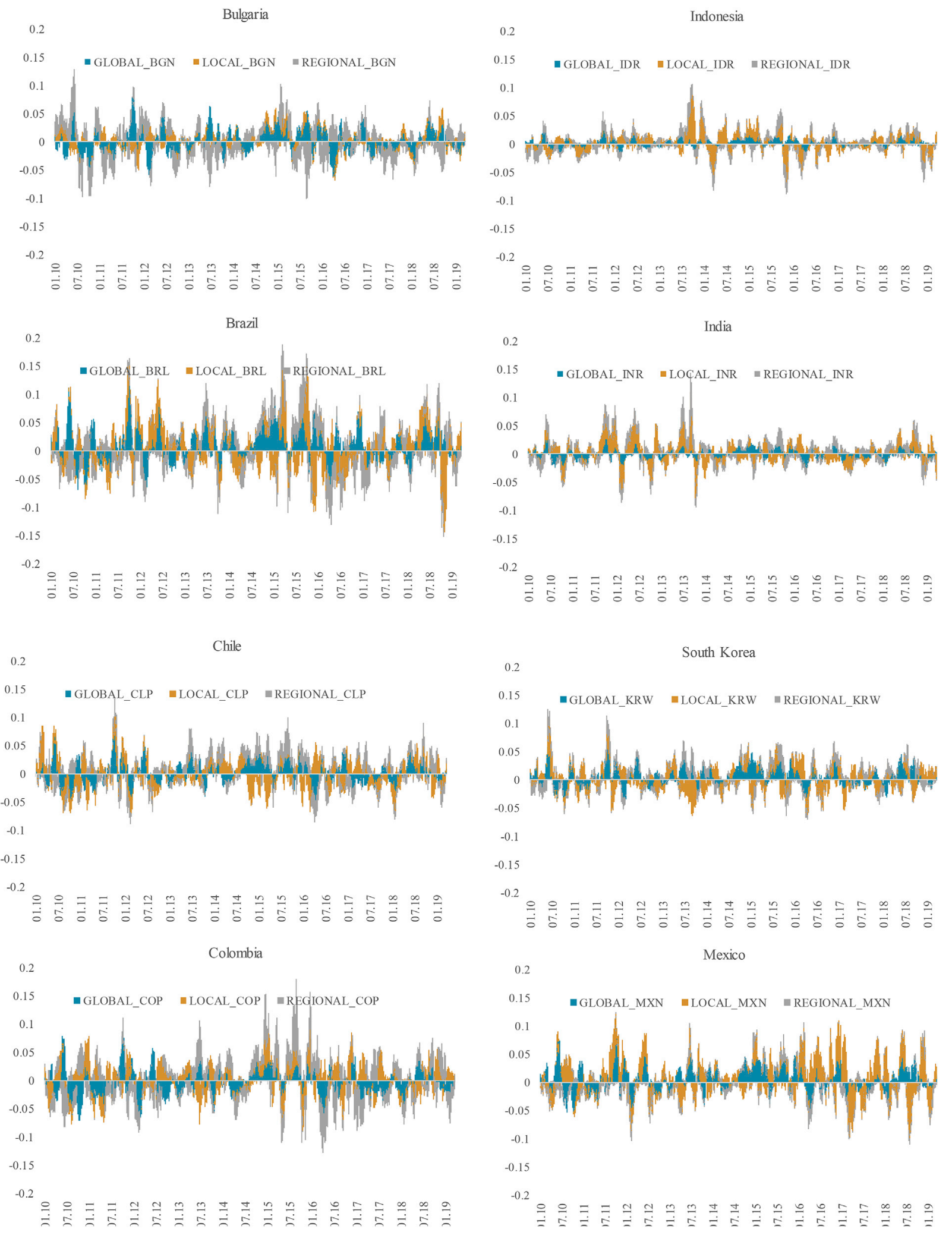

A3. Global, Local and Regional Factors in Emerging Market FX Markets 

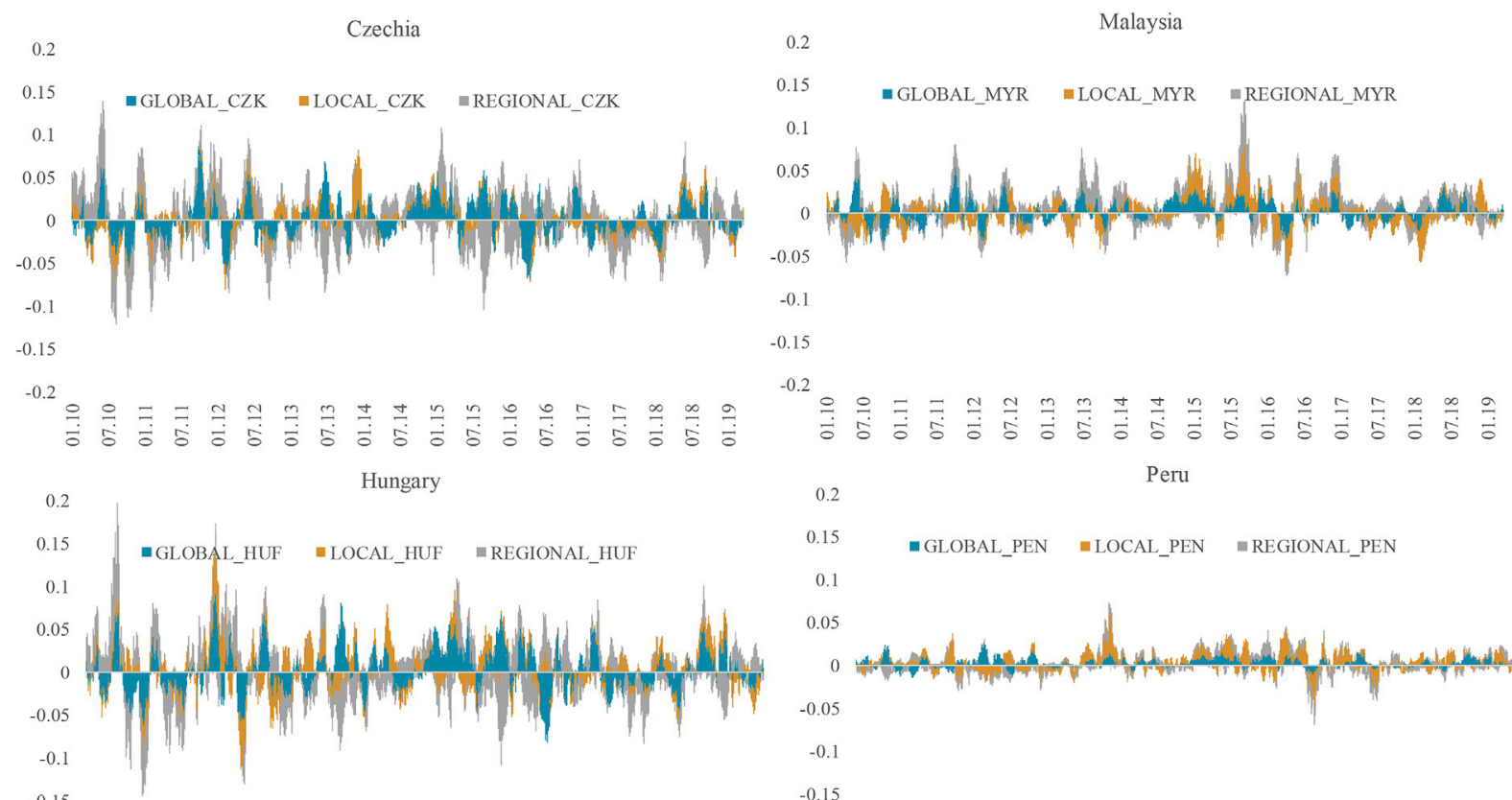

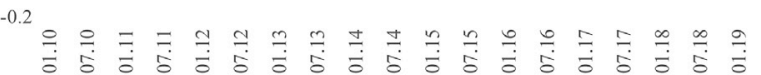
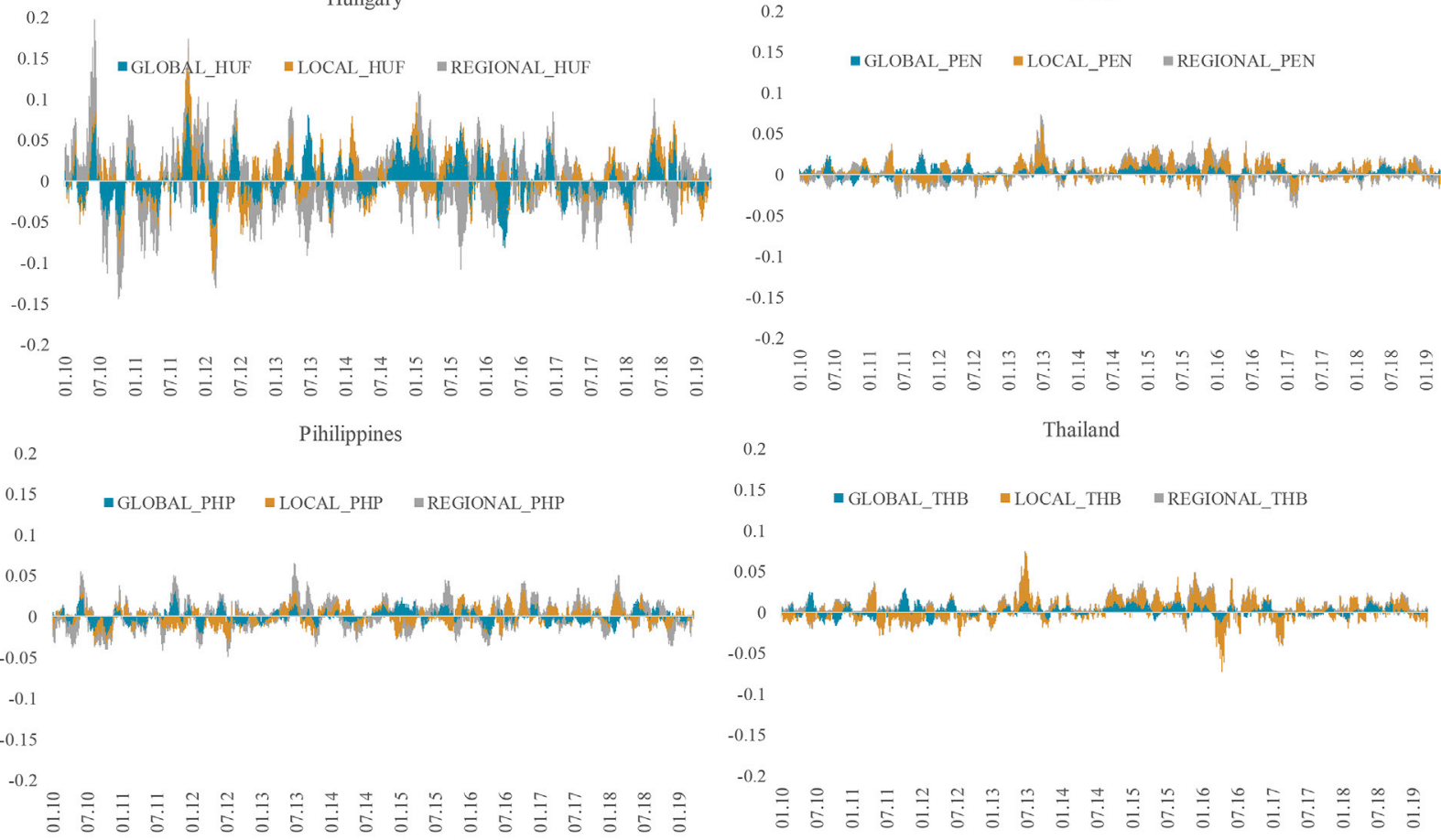

$-0.1$

$-0.15$

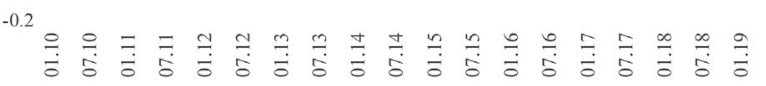
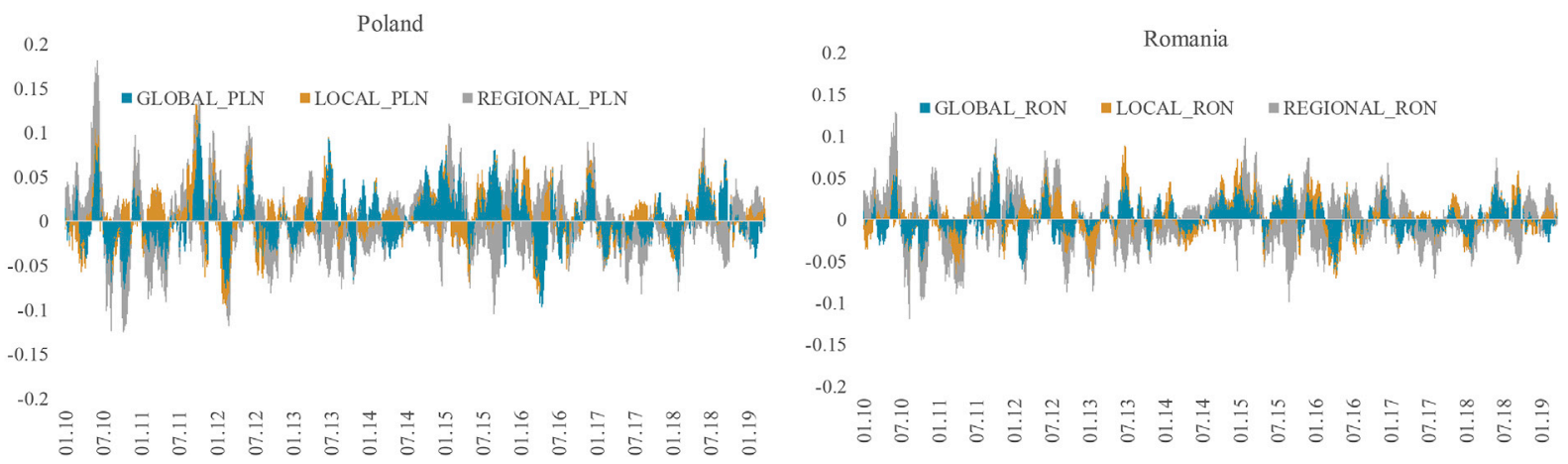

A3. . (continued). 


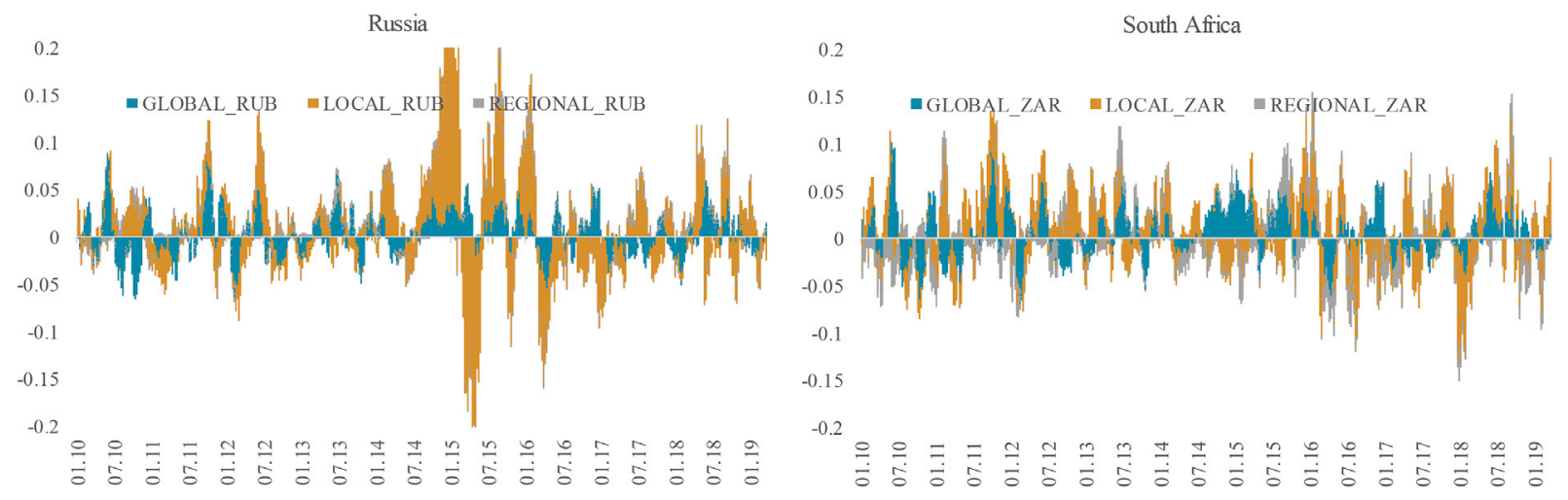

A3. . (continued).

0.2

Turkey

$$
0.15
$$

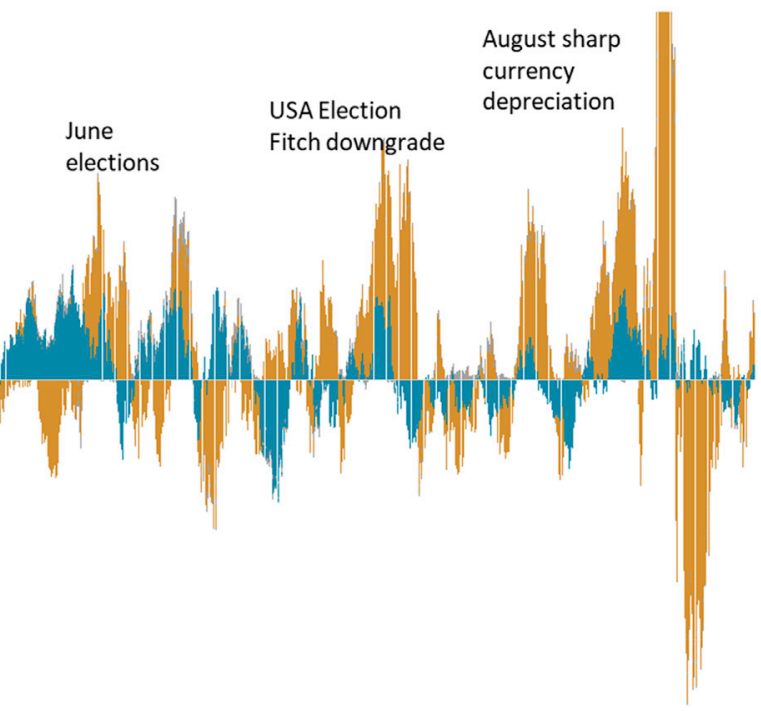

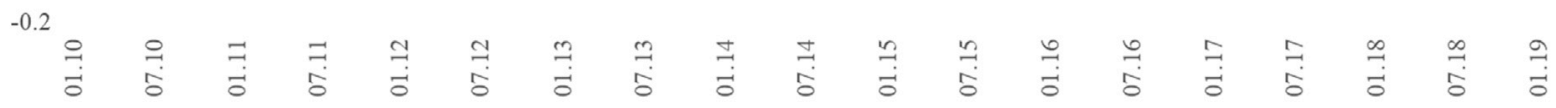

$$
\begin{aligned}
& \text { mGLOBAL_TR } \quad \text { EOCAL_TR }
\end{aligned}
$$

A4. Global, Local and Regional Shocks in Turkey's FX Market

A5

Descriptive Statistics of Local Shocks

\begin{tabular}{lllll}
\hline Country & Mean & Min & Max & Stdev \\
\hline TRY & 0.753 & -16.776 & 38.797 & 4.339 \\
RUB & 0.723 & -22.691 & 45.400 & 4.962 \\
COP & 0.365 & -7.837 & 8.241 & 2.110 \\
MXN & 0.270 & -10.667 & 9.401 & 2.808 \\
INR & -7.001 & 10.095 & 1.817 \\
PLN & 0.266 & -3.374 & 4.928 & 1.307 \\
ZAR & 0.240 & -12.574 & 11.153 & 3.077 \\
PEN & 0.236 & -4.724 & 4.662 & 1.075 \\
HUF & 0.176 & -5.992 & 5.613 & 1.585 \\
BGN & 0.159 & -2.550 & 2.924 & 0.845 \\
THB & 0.145 & -5.750 & 5.790 & 1.272 \\
CZK & 0.138 & -3.891 & 6.063 & 1.104 \\
MYR & 0.094 & -4.286 & 7.255 & 1.513 \\
IDR & 0.033 & -7.091 & 9.425 & 1.763
\end{tabular}


A5 (continued)

\begin{tabular}{lllll}
\hline Country & Mean & Min & Max & Stdev \\
\hline RON & 0.023 & -5.441 & 4.596 & 1.194 \\
PHP & -0.033 & -3.120 & 3.731 & 1.042 \\
CLP & -0.067 & -6.150 & 6.338 & 2.002 \\
BRL & -0.088 & -14.547 & 13.166 & 3.126 \\
KRW & -0.110 & -6.518 & 6.409 & 1.810 \\
\hline Average & $\mathbf{0 . 1 7 7}$ & $\mathbf{- 7 . 9 4 6}$ & $\mathbf{1 0 . 7 3 6}$ & $\mathbf{2 . 0 4 0}$ \\
\hline
\end{tabular}

This table presents the descriptive statistics of local shocks. They are calculated from the daily local shocks between January 01 , 2010 and March 18, 2019. Positive values indicate the depreciating shocks whereas negative values indicate appreciating shocks.

A6

Descriptive Statistics of Positive and Negative Local Shocks

\begin{tabular}{|c|c|c|c|c|c|}
\hline Positive Local Shocks & Mean & Stdev & Count & Share (\%) & Total Effect \\
\hline RUB & -2.648 & 3.209 & 1110 & 46.2 & -2939 \\
\hline BRL & -2.391 & 2.229 & 1203 & 50.1 & -2877 \\
\hline ZAR & -2.249 & 1.946 & 1149 & 47.8 & -2584 \\
\hline TRY & -2.163 & 2.498 & 1125 & 46.8 & -2433 \\
\hline MXN & -1.937 & 1.853 & 1140 & 47.5 & -2208 \\
\hline CLP & -1.626 & 1.247 & 1217 & 50.7 & -1979 \\
\hline KRW & -1.516 & 1.148 & 1228 & 51.1 & -1861 \\
\hline $\mathrm{COP}$ & -1.427 & 1.230 & 1088 & 45.3 & -1553 \\
\hline IDR & -1.226 & 1.243 & 1153 & 48.0 & -1414 \\
\hline MYR & -1.096 & 0.854 & 1221 & 50.8 & -1338 \\
\hline INR & -1.177 & 1.075 & 1119 & 46.6 & -1317 \\
\hline HUF & -1.112 & 0.917 & 1150 & 47.9 & -1279 \\
\hline RON & -0.866 & 0.848 & 1183 & 49.3 & -1024 \\
\hline PHP & -0.826 & 0.610 & 1238 & 51.5 & -1023 \\
\hline THB & -0.850 & 0.761 & 1155 & 48.1 & -982 \\
\hline PLN & -0.865 & 0.695 & 1087 & 45.3 & -941 \\
\hline $\mathrm{CZK}$ & -0.735 & 0.608 & 1149 & 47.8 & -845 \\
\hline PEN & -0.691 & 0.601 & 1104 & 46.0 & -763 \\
\hline BGN & -0.544 & 0.454 & 1111 & 46.3 & -604 \\
\hline Average & -1.366 & 1.265 & 1154 & 48.1 & -1576 \\
\hline Negative Local Shocks & Mean & Stdev & Count & Share (\%) & Total Effect \\
\hline RUB & 3.619 & 4.334 & 1292 & 53.8 & 4675 \\
\hline TRY & 3.321 & 3.980 & 1277 & 53.2 & 4240 \\
\hline ZAR & 2.514 & 1.956 & 1253 & 52.2 & 3150 \\
\hline MXN & 2.264 & 1.879 & 1262 & 52.5 & 2858 \\
\hline BRL & 2.223 & 1.980 & 1199 & 49.9 & 2665 \\
\hline $\mathrm{COP}$ & 1.849 & 1.422 & 1314 & 54.7 & 2430 \\
\hline INR & 1.524 & 1.331 & 1283 & 53.4 & 1956 \\
\hline CLP & 1.535 & 1.211 & 1185 & 49.3 & 1819 \\
\hline HUF & 1.326 & 1.095 & 1252 & 52.1 & 1660 \\
\hline KRW & 1.360 & 1.048 & 1174 & 48.9 & 1597 \\
\hline PLN & 1.153 & 0.935 & 1315 & 54.7 & 1516 \\
\hline IDR & 1.193 & 1.320 & 1249 & 52.0 & 1490 \\
\hline MYR & 1.201 & 1.105 & 1181 & 49.2 & 1418 \\
\hline THB & 1.053 & 0.917 & 1247 & 51.9 & 1313 \\
\hline PEN & 0.913 & 0.804 & 1298 & 54.0 & 1185 \\
\hline RON & 0.885 & 0.775 & 1219 & 50.7 & 1079 \\
\hline CZK & 0.855 & 0.888 & 1253 & 52.2 & 1071 \\
\hline BGN & 0.738 & 0.626 & 1291 & 53.7 & 953 \\
\hline PHP & 0.811 & 0.680 & 1164 & 48.5 & 944 \\
\hline Average & 1.597 & 1.489 & 1248 & 51.9 & 1992 \\
\hline
\end{tabular}

This table presents the descriptive statistics of local shocks. They are calculated from the daily local shocks between January 01 , 2010 and March 18, 2019. Positive values indicate the depreciating shocks whereas negative values indicate appreciating shocks. Count is the total number of positive/negative shocks in all shocks and Share shows the share of negative/positive shocks in total shocks. Total effect is the multiplication of the count and mean which indicates the strength of shocks.

A7

Descriptive Statistics of Global Shocks

\begin{tabular}{lllll}
\hline Country & Mean & Min & Max & Stdev \\
\hline BRL & 0.864 & -7.426 & 12.526 & 3.076 \\
KRW & 0.491 & -4.245 & 6.998 & 1.748 \\
ZAR & 0.490 & -7.672 & 11.542 & 2.912
\end{tabular}


A7 (continued)

\begin{tabular}{lllll}
\hline Country & Mean & Min & Max & Stdev \\
\hline MXN & 0.390 & -6.055 & 8.853 & 2.243 \\
TRY & 0.327 & -6.627 & 9.926 & 2.479 \\
PEN & 0.281 & -1.406 & 2.719 & 0.629 \\
MYR & -3.822 & 5.922 & 1.489 \\
RUB & -6.840 & 10.116 & 2.574 \\
THB & 0.232 & -1.663 & 2.935 & 0.702 \\
HUF & 0.214 & -8.139 & 10.761 & 2.879 \\
PLN & 0.188 & -9.744 & 13.139 & 3.447 \\
IDR & 0.145 & -1.937 & 2.939 & 0.737 \\
RON & 0.125 & -6.368 & 8.770 & 2.286 \\
BGN & -6.367 & 8.806 & 2.297 \\
CLP & 0.112 & -5.917 & 7.784 & 2.091 \\
CZK & 0.100 & -7.023 & 9.450 & 2.485 \\
PHP & 0.087 & -2.688 & 3.682 & 0.968 \\
INR & 0.045 & -2.839 & 3.641 & 0.978 \\
COP & -0.014 & -7.304 & 8.864 & 2.455 \\
\hline Average & -0.068 & -5.478 & $\mathbf{7 . 8 6 2}$ & $\mathbf{2 . 0 2 5}$ \\
\hline
\end{tabular}

This table presents the descriptive statistics of global shocks. They are calculated from the daily global shocks between January 01 , 2010 and March 18, 2019. Positive values indicate the depreciating shocks whereas negative values indicate appreciating shocks. A8

Descriptive Statistics of Positive and Negative Global Shocks

\begin{tabular}{|c|c|c|c|c|c|}
\hline Positive Global Shocks & Mean & Stdev & Count & Share (\%) & Total Effect \\
\hline PLN & -2.543 & 1.843 & 1240 & 51.6 & -3153 \\
\hline $\mathrm{COP}$ & -2.126 & 1.439 & 1441 & 60.0 & -3064 \\
\hline HUF & -2.090 & 1.525 & 1220 & 50.8 & -2550 \\
\hline CZK & -1.849 & 1.339 & 1265 & 52.7 & -2338 \\
\hline ZAR & -1.985 & 1.525 & 1114 & 46.4 & -2211 \\
\hline RUB & -1.846 & 1.380 & 1190 & 49.5 & -2196 \\
\hline BGN & -1.694 & 1.226 & 1234 & 51.4 & -2090 \\
\hline RON & -1.679 & 1.227 & 1230 & 51.2 & -2065 \\
\hline TRY & -1.738 & 1.304 & 1145 & 47.7 & -1990 \\
\hline BRL & -1.962 & 1.553 & 1009 & 42.0 & -1979 \\
\hline CLP & -1.541 & 1.131 & 1238 & 51.5 & -1908 \\
\hline MXN & -1.542 & 1.181 & 1100 & 45.8 & -1697 \\
\hline MYR & -1.028 & 0.785 & 1118 & 46.5 & -1149 \\
\hline KRW & -1.119 & 0.876 & 1008 & 42.0 & -1128 \\
\hline INR & -0.770 & 0.550 & 1342 & 55.9 & -1033 \\
\hline PHP & -0.740 & 0.532 & 1284 & 53.5 & -951 \\
\hline IDR & -0.505 & 0.387 & 1109 & 46.2 & -560 \\
\hline THB & -0.442 & 0.351 & 983 & 40.9 & -434 \\
\hline PEN & -0.365 & 0.302 & 843 & 35.1 & -308 \\
\hline Average & -1.451 & 1.077 & 1164 & 48.5 & -1688.4 \\
\hline Negative Global Shocks & Mean & Stdev & Count & Share (\%) & Total Effect \\
\hline BRL & 2.911 & 2.143 & 1393 & 58.0 & 4056 \\
\hline PLN & 3.013 & 2.236 & 1162 & 48.4 & 3501 \\
\hline ZAR & 2.630 & 1.980 & 1288 & 53.6 & 3387 \\
\hline HUF & 2.539 & 1.886 & 1182 & 49.2 & 3001 \\
\hline TRY & 2.207 & 1.663 & 1257 & 52.3 & 2775 \\
\hline RUB & 2.272 & 1.692 & 1212 & 50.5 & 2754 \\
\hline MXN & 2.022 & 1.512 & 1302 & 54.2 & 2633 \\
\hline CZK & 2.152 & 1.620 & 1137 & 47.3 & 2447 \\
\hline RON & 1.991 & 1.494 & 1172 & 48.8 & 2334 \\
\hline BGN & 1.995 & 1.506 & 1168 & 48.6 & 2330 \\
\hline KRW & 1.655 & 1.217 & 1394 & 58.0 & 2307 \\
\hline CLP & 1.820 & 1.356 & 1164 & 48.5 & 2118 \\
\hline $\mathrm{COP}$ & 1.896 & 1.499 & 961 & 40.0 & 1822 \\
\hline MYR & 1.337 & 1.004 & 1284 & 53.5 & 1717 \\
\hline PEN & 0.631 & 0.460 & 1559 & 64.9 & 984 \\
\hline THB & 0.668 & 0.494 & 1419 & 59.1 & 949 \\
\hline PHP & 0.821 & 0.619 & 1118 & 46.5 & 918 \\
\hline INR & 0.820 & 0.610 & 1060 & 44.1 & 870 \\
\hline IDR & 0.666 & 0.498 & 1293 & 53.8 & 861 \\
\hline Total & 1.792 & 1.341 & 1238 & 51.5 & 2218.7 \\
\hline
\end{tabular}

This table presents the descriptive statistics of global shocks. They are calculated from the daily global shocks between January 01 , 2010 and March 18, 2019. Positive values indicate the depreciating shocks whereas negative values indicate appreciating shocks. Count 
is the total number of positive/negative shocks in all shocks and Share shows the share of negative/positive shocks in total shocks. Total effect is the multiplication of the count and mean which indicates the strength of shocks.

A9

Descriptive Statistics of Regional Shocks

\begin{tabular}{lllll}
\hline Country & Mean & Min & Max & Stdev \\
\hline MYR & 0.299 & -2.779 & 4.588 & 1.070 \\
CLP & 0.226 & -3.777 & 5.964 & 1.224 \\
KRW & 0.127 & -2.025 & 3.124 & 0.748 \\
TRY & -0.685 & 1.157 & 0.225 \\
INR & 0.122 & -2.307 & 3.471 & 0.839 \\
RUB & 0.107 & -0.541 & 0.172 \\
THB & 0.076 & -0.377 & 0.367 & 0.110 \\
PHP & 0.065 & -2.263 & 0.801 \\
COP & 0.043 & -7.384 & 3.256 & 2.268 \\
IDR & 0.030 & -2.109 & 10.656 & 0.735 \\
PEN & -1.711 & 2.950 & 0.502 \\
CZK & -0.070 & -10.373 & 2.283 & 2.238 \\
BRL & -0.094 & -5.856 & 7.922 & 1.759 \\
ZAR & -0.106 & -2.992 & 8.136 & 0.789 \\
MXN & -0.167 & -1.706 & 3.455 & 0.470 \\
BGN & -0.168 & -9.880 & 2.036 & 2.111 \\
HUF & -0.184 & -10.290 & 7.378 & 2.196 \\
RON & -0.205 & -9.919 & 7.661 & 2.114 \\
PLN & -0.207 & -9.790 & 7.367 & 2.078 \\
\hline Average & -0.246 & -4.567 & 7.198 & $\mathbf{1 . 1 8 2}$ \\
\hline
\end{tabular}

This table presents the descriptive statistics of regional shocks. They are calculated from the daily regional shocks between January 01, 2010 and March 18, 2019. Positive values indicate the depreciating shocks whereas negative values indicate appreciating shocks. A10

Descriptive Statistics of Positive and Negative Regional Shocks

\begin{tabular}{|c|c|c|c|c|c|}
\hline Positive Regional Shocks & Mean & Stdev & Count & Share (\%) & Total Effect \\
\hline CZK & -1.835 & 1.539 & 1204 & 50.1 & -2209 \\
\hline HUF & -1.818 & 1.526 & 1268 & 52.8 & -2306 \\
\hline RON & -1.758 & 1.470 & 1270 & 52.9 & -2233 \\
\hline COP & -1.755 & 1.361 & 1191 & 49.6 & -2091 \\
\hline BGN & -1.744 & 1.466 & 1262 & 52.5 & -2201 \\
\hline PLN & -1.736 & 1.451 & 1295 & 53.9 & -2248 \\
\hline BRL & -1.417 & 1.075 & 1255 & 52.2 & -1779 \\
\hline CLP & -0.856 & 0.706 & 1046 & 43.5 & -895 \\
\hline MYR & -0.695 & 0.586 & 937 & 39.0 & -651 \\
\hline ZAR & -0.665 & 0.477 & 1451 & 60.4 & -964 \\
\hline INR & -0.571 & 0.477 & 1125 & 46.8 & -642 \\
\hline PHP & -0.566 & 0.463 & 1206 & 50.2 & -683 \\
\hline IDR & -0.531 & 0.429 & 1259 & 52.4 & -668 \\
\hline KRW & -0.501 & 0.421 & 1075 & 44.8 & -538 \\
\hline MXN & -0.431 & 0.315 & 1557 & 64.8 & -671 \\
\hline PEN & -0.422 & 0.313 & 1324 & 55.1 & -559 \\
\hline TRY & -0.126 & 0.107 & 740 & 30.8 & -93 \\
\hline RUB & -0.104 & 0.084 & 815 & 33.9 & -85 \\
\hline THB & -0.078 & 0.071 & 596 & 24.8 & -46 \\
\hline Average & -0.927 & 0.755 & 1151 & 47.9 & -1067 \\
\hline Negative Regional Shocks & Mean & Stdev & Count & Share (\%) & Total Effect \\
\hline $\mathrm{COP}$ & 1.786 & 1.471 & 1211 & 50.4 & 2162 \\
\hline CZK & 1.655 & 1.249 & 1198 & 49.9 & 1982 \\
\hline HUF & 1.600 & 1.200 & 1134 & 47.2 & 1814 \\
\hline BGN & 1.543 & 1.156 & 1140 & 47.5 & 1759 \\
\hline RON & 1.533 & 1.154 & 1132 & 47.1 & 1735 \\
\hline PLN & 1.498 & 1.125 & 1107 & 46.1 & 1659 \\
\hline BRL & 1.330 & 1.128 & 1147 & 47.8 & 1525 \\
\hline CLP & 1.061 & 0.819 & 1356 & 56.5 & 1439 \\
\hline MYR & 0.935 & 0.788 & 1465 & 61.0 & 1370 \\
\hline INR & 0.705 & 0.602 & 1277 & 53.2 & 900 \\
\hline PHP & 0.657 & 0.568 & 1196 & 49.8 & 786 \\
\hline KRW & 0.635 & 0.540 & 1327 & 55.2 & 842 \\
\hline IDR & 0.595 & 0.517 & 1143 & 47.6 & 680 \\
\hline ZAR & 0.591 & 0.520 & 951 & 39.6 & 562 \\
\hline PEN & 0.363 & 0.319 & 1078 & 44.9 & 391 \\
\hline MXN & 0.316 & 0.291 & 845 & 35.2 & 267 \\
\hline
\end{tabular}


A10 (continued)

\begin{tabular}{llllll}
\hline Positive Regional Shocks & Mean & Stdev & Count & Share (\%) & Total Effect \\
\hline TRY & 0.232 & 0.170 & 1662 & 69.2 & 386 \\
RUB & 0.168 & 0.127 & 1587 & 66.1 & 267 \\
THB & 0.112 & 0.074 & 1806 & $\mathbf{7 5 . 2}$ & 202 \\
\hline Average & $\mathbf{0 . 9 1 1}$ & $\mathbf{0 . 7 2 7}$ & $\mathbf{1 2 5 1}$ & $\mathbf{5 2 . 1}$ & $\mathbf{1 1 4 0}$ \\
\hline
\end{tabular}

This table presents the descriptive statistics of regional shocks. They are calculated from the daily regional shocks between January 01, 2010 and March 18, 2019. Positive values indicate the depreciating shocks whereas negative values indicate appreciating shocks. Count is the total number of positive/negative shocks in all shocks and Share shows the share of negative/positive shocks in total shocks. Total effect is the multiplication of the count and mean which indicates the strength of shocks.

A11

Descriptive Statistics of Total Shocks

\begin{tabular}{|c|c|c|c|c|c|}
\hline Currency & Mean & Min & Max & Stdev & t-stat \\
\hline TRY & 1.201 & -17.721 & 40.375 & 5.098 & 11.55 \\
\hline RUB & 1.031 & -21.490 & 49.422 & 6.075 & 8.32 \\
\hline BRL & 0.671 & -13.227 & 18.830 & 4.872 & 6.75 \\
\hline MYR & 0.569 & -7.302 & 13.250 & 2.661 & 10.48 \\
\hline ZAR & 0.558 & -15.082 & 15.447 & 4.533 & 6.03 \\
\hline KRW & 0.507 & -7.023 & 12.438 & 2.698 & 9.21 \\
\hline MXN & 0.492 & -10.510 & 12.343 & 3.775 & 6.39 \\
\hline THB & 0.417 & -7.094 & 7.273 & 1.479 & 13.82 \\
\hline PEN & 0.387 & -6.888 & 7.356 & 1.460 & 13.00 \\
\hline INR & 0.305 & -9.569 & 14.283 & 2.697 & 5.54 \\
\hline CLP & 0.247 & -9.001 & 13.319 & 3.130 & 3.87 \\
\hline IDR & 0.162 & -8.828 & 10.283 & 2.361 & 3.37 \\
\hline HUF & 0.142 & -14.508 & 19.744 & 4.113 & 1.69 \\
\hline PLN & 0.139 & -12.324 & 18.218 & 4.046 & 1.68 \\
\hline BGN & 0.061 & -9.682 & 10.649 & 2.989 & 1.00 \\
\hline CZK & 0.045 & -12.130 & 12.891 & 3.660 & 0.60 \\
\hline PHP & -0.004 & -5.018 & 6.541 & 1.686 & -0.11 \\
\hline RON & -0.073 & -11.932 & 12.620 & 3.359 & -1.06 \\
\hline $\mathrm{COP}$ & -0.122 & -12.246 & 17.980 & 4.127 & -1.45 \\
\hline Average & 0.355 & -11.135 & 16.487 & 3.412 & \\
\hline
\end{tabular}

This table presents the descriptive statistics of total shocks. They are calculated from the daily total shocks between January 01 , 2010 and March 18, 2019. Positive values indicate the depreciating shocks whereas negative values indicate appreciating shocks. The currencies that have t-stats larger than 1.96 indicate that the shocks are statistically significant.

A12

Carry Return (\%)

\begin{tabular}{ll}
\hline Currency & Mean \\
\hline TRY & 9.043 \\
BRL & 8.427 \\
RUB & 7.106 \\
INR & 6.088 \\
ZAR & 5.916 \\
IDR & 5.724 \\
MXN & 3.873 \\
PLN & 3.172 \\
CLP & 2.992 \\
COP & 2.882 \\
RON & 2.185 \\
PEN & 1.904 \\
PHP & 1.804 \\
HUF & 1.523 \\
THB & 1.503 \\
KRW & 1.243 \\
CZK & -0.751 \\
\hline
\end{tabular}

\section{References}

Aizenman, J., \& Binici, M. (2016). Exchange market pressure in OECD and emerging economies: Domestic vs. external factors and capital flows in the old and new normal. Journal of International Money and Finance, 66, 65-87.

Aizenman, J., \& Pinto, B. (2011). Managing Financial Integration and Capital Mobility-policy lessons from the past two decades. Review of International Economics, 21(4), 636-653. 
Brana, S., \& Lahet, D. (2010). Determinants of capital inflows into Asia: The relevance of contagion effects as push factors. Emerging Markets Review, 11(3), 273-284. Arellano, M., \& Bover, O. (1995). Another look at the instrumental variable estimation of error-components models. Journal of Econometrics, 68(1), 29-51. Bruno, V., \& Shin, H. S. (2015). Capital flows and the risk-taking channel of monetary policy. Journal of Monetary Economics, 71, 119-132.

Burger, J. D., Sengupta, R., Warnock, F. E., \& Warnock, V. C. (2015). US investment in global bonds: As the Fed pushes, some EMEs pull. Economic Policy, 30(84), $729-766$.

Byrne, J. P., \& Fiess, N. (2016). International capital flows to emerging markets: National and global determinants. Journal of International Money and Finance, 61, $82-100$.

Calvo, G. A., Leiderman, L., \& Reinhart, C. M. (1993). Capital inflows and real exchange rate appreciation in Latin America: The role of external factors. Staff Papers, 40(1), 108-151.

Cerutti, E., Claessens, S., \& Rose, A. K. (2019). How important is the global financial cycle? Evidence from capital flows. IMF Economic Review, 67(1), 24-60.

Chinn, M. (2007). Forward premium puzzle. World economy-forward premium puzzle (entry written for the princeton encyclopedia of the world economy) (pp. 1-8),

Chinn, M. D., \& Meredith, G. (2004). Monetary policy and long-horizon uncovered interest parity. IMF Staff Papers, 51(3), 409-430.

Chuhan, P., Claessens, S., \& Mamingi, N. (1998). Equity and bond flows to Latin America and asia: The role of global and country factors. Journal of Development Economics, 55(2), 439-463.

Dailami, M., Masson, P. R., \& Padou, J. J. (2008). Global monetary conditions versus country-specific factors in the determination of emerging market debt spreads. Journal of International Money and Finance, 27(8), 1325-1336.

Dos Santos, M. B. C., Klotzle, M. C., \& Pinto, A. C. F. (2016). Evidence of risk premiums in emerging market carry trade currencies. Journal of International Financial Markets, Institutions and Money, 44, 103-115.

Edwards, S., \& Yeyati, E. L. (2005). Flexible exchange rates as shock absorbers. European Economic Review, 49(8), 2079-2105.

Fama, E. F. (1984). Forward and spot exchange rates. Journal of Monetary Economics, 14, 319-338.

Fernandez-Arias, E., \& Montiel, P. J. (1996). The surge in capital inflows to developing countries: An analytical overview. The World Bank Economic Review, 10(1), 51-77.

Flood, R. P., \& Rose, A. K. (1995). Fixing exchange rates, a virtual quest for fundamentals. Journal of Monetary Economics, 36(1), 3-37.

Forbes, K., Hjortsoe, I., \& Nenova, T. (2018). The shocks matter: Improving our estimates of exchange rate pass-through. Journal of International Economics, 114, $255-275$.

Forbes, K. J., \& Warnock, F. E. (2012). Capital flow waves: Surges, stops, flight, and retrenchment. Journal of International Economics, 88(2), $235-251$.

Frankel, J. A. (1979). On the mark: A theory of floating exchange rates based on real interest differentials. The American Economic Review, 69(4), 610-622.

Frankel, J., \& Poonawala, J. (2010). The forward market in emerging currencies: Less biased than in major currencies. Journal of International Money and Finance, 29(3), 585-598.

Fratzscher, M. (2012). Capital flows, push versus pull factors and the global financial crisis. Journal of International Economics, 88(2), 341-356.

Froot, K. A., \& Thaler, R. H. (1990). Anomalies: Foreign exchange. The Journal of Economic Perspectives, 4(3), 179-192.

Ghosh, A. R., Ostry, J. D., \& Chamon, M. (2016). Two targets, two instruments: Monetary and exchange rate policies in emerging market economies. Journal of International Money and Finance, 60, 172-196.

Gilchrist, S., Yankov, V., \& Zakrajšek, E. (2009). Credit market shocks and economic fluctuations: Evidence from corporate bond and stock markets. Journal of Monetary Economics, 56(4), 471-493.

Hibbert, A. M., \& Pavlova, I. (2017). The drivers of sovereign CDS spread changes: Local versus global factors. Financial Review, 52(3), 435-457.

Ismailov, A., \& Rossi, B. (2018). Uncertainty and deviations from uncovered interest rate parity. Journal of International Money and Finance, 88, $242-259$.

Izquierdo, A., Romero-Aguilar, R., \& Talvi, E. (2008). Booms and busts in Latin America: The role of external factors. RES working paper 4569. Washington: Inter-American Development Bank, Research Department.

Jermann, U., \& Quadrini, V. (2012). Macroeconomic effects of financial shocks. The American Economic Review, 102(1), 238-271.

Kennedy, M., \& Palerm, A. (2014). Emerging market bond spreads: The role of global and domestic factors from 2002 to 2011 . Journal of International Money and Finance, 43, 70-87.

Kim, S. (2001). International transmission of US monetary policy shocks: Evidence from VAR's. Journal of Monetary Economics, 48(2), 339-372.

Koepke, R. (2019). What drives capital flows to emerging markets? A survey of the empirical literature. Journal of Economic Surveys, 33(2), 516-540.

Kumar, S., \& Trück, S. (2014). Unbiasedness and risk premiums in the Indian currency futures market. Journal of International Financial Markets, Institutions and Money, $29,13-32$.

Lane, P. R. (2003). Business cycles and macroeconomic policy in emerging market economies. International Finance, 6(1), 89-108.

Levich, R. M. (1983). Empirical studies of exchange rates: Price behaviour, rate determination and market efficiency. In Working paper (Vol. 1112). Cambridge: M.A. Lewis, K. (1995). Puzzles in international financial markets. In G. Grossman, \& K. Rogoff (Eds.), Handbook of international economics (Vol. 3, pp. 1913-1971). Elsevier. Maćkowiak, B. (2007). External shocks, US monetary policy and macroeconomic fluctuations in emerging markets. Journal of Monetary Economics, 54(8), 2512-2520. Maynard, A. (2003). Testing for forward-rate unbiasedness: On regression in levels and in returns. The Review of Economics and Statistics, 85(2), 313-327.

Nikolaou, K., \& Sarno, L. (2006). New evidence on the forward unbiasedness hypothesis in the foreign exchange market. Journal of Futures Markets, 26 , 627-656. Siklos, P. L. (2018). Boom-and-bust cycles in emerging markets: How important is the exchange rate? Journal of Macroeconomics, 56, $172-187$.

Tai, C. S. (2003). Can currency risk be a source of risk premium in explaining forward premium puzzle? Evidence from asia-pacific forward exchange markets. Journal of International Financial Markets, Institutions and Money, 13, 291-311.

Taylor, M. P., \& Sarno, L. (1997). Capital flows to developing countries: Long-and short-term determinants. The World Bank Economic Review, 11(3), 451-470. 